of 87 elected MPs and the committees meet several times a year, as required. Every year the Nordic Council grants prizes for literature, music, nature and environment.

Members. Denmark (including the Faroe Islands and Greenland), Finland (including Åland), Iceland, Norway, Sweden.

Address: Ved Stranden 18, DK-1061 Copenhagen K, Denmark. Website: http://www.norden.org

Email: nordisk-rad@norden.org

President: Kimmo Sasi (Finland).

\section{Nordic Development Fund (NDF)}

$\mathrm{NDF}$ is a multilateral development finance institution established by the five Nordic countries, Denmark, Finland, Iceland, Norway and Sweden. Since operations started in 1989, the Fund has provided soft loans to 190 projects of Nordic interest in developing countries. It entered a new phase in 2009 and changed its focus to grant aid for climate change related projects.

Address: Fabianinkatu 34, PO Box 185, FIN-00171 Helsinki,

Finland.

Website: http://www.ndf.fi

Email: info.ndf@ndf.fi

Managing Director: Helge Semb (Norway).

\section{Nordic Investment Bank (NIB)}

The Nordic Investment Bank, which commenced operations in 1976, is a multilateral financial institution owned by Denmark, Estonia, Finland, Iceland, Latvia, Lithuania, Norway and Sweden. It finances public and private projects both within and outside the Nordic area. Priority is given to projects furthering economic co-operation between the member countries or improving the environment. Focal points include the neighbouring areas of the member countries.

Address: Fabianinkatu 34, PO Box 249, FI-00171 Helsinki,

Finland.

Website: http://www.nib.int

Email: info@nib.int

President: Johnny Åkerholm (Finland).

\section{Council of the Baltic Sea States}

Established in 1992 in Copenhagen following a conference of ministers of foreign affairs.

Members. Denmark, Estonia, Finland, Germany, Iceland, Latvia, Lithuania, Norway, Poland, Russia, Sweden and the European Commission.

Aims. To promote co-operation in the Baltic Sea region in the field of trade, investment and economic exchanges, combating organized crime, civil security, culture and education, transport and communication, energy and environment, human rights and assistance to democratic institutions.

The Council meets at ministerial level once a year, chaired by rotating foreign ministers; it is the supreme decision-making body. Between annual sessions the Committee of Senior Officials and three working groups meet at regular intervals. In 1999 ministers of energy of the CBSS member states agreed to achieve the goal of creating effective, economically and environmentally sound and more integrated energy systems in the Baltic Sea region. Eight summits at the level of heads of government of CBSS member states and the President of the European Commission have taken place; in 1996, 1998, 2000, 2002, 2004, 2006, 2008 and 2010. The Baltic Sea Region Energy Cooperation (BASREC) is made up of energy ministers from the region and is chaired by the energy minister from the chair country of the CBSS.

Official language: English.

CBSS Secretariat: Strömsborg, PO Box 2010, S-103 11

Stockholm, Slussplan 9, Sweden.

Website: http://www.cbss.org

Director of the Secretariat: Jan Lundin (Sweden).

\section{European Broadcasting Union (EBU)}

Founded in 1950 by western European radio and television broadcasters, the EBU is the world's largest professional association of national broadcasters, with 74 active members in 56 countries of Europe, North Africa and the Middle East, and 37 associate members worldwide.

The EBU merged with the OIRT, its counterpart in eastern Europe, in 1993. The EBU's Eurovision Operations Department has a permanent network offering 50 digital channels on five satellites. Two satellite channels also relay radio concerts, operas, sports fixtures and major news events for Euroradio.

Headquarters: Ancienne Route 17A, CH-1218 Grand-Saconnex, Geneva, Switzerland.

Website: http://www.ebu.ch

Email: ebu@ebu.ch

Director-General: Ingrid Deltenre (Netherlands).

\section{Black Sea Economic Cooperation (BSEC)}

Founded in 1992 to promote economic co-operation in the Black Sea region. Priority areas of interest include: trade and economic development; banking and finance; communications; energy; transport; agriculture and agro-industry; healthcare and pharmaceutics; environmental protection; tourism; science and technology; exchange of statistical data and economic information; combating organized crime, illicit trafficking of drugs, weapons and radioactive materials, all acts of terrorism and illegal immigration.

Members. Albania, Armenia, Azerbaijan, Bulgaria, Georgia, Greece, Moldova, Romania, Russia, Serbia, Turkey, Ukraine.

Observers. Austria, Belarus, Black Sea Commission, Commission of the European Communities, Croatia, Czech Republic, Egypt, Energy Charter Secretariat, France, Germany, International Black Sea Club, Israel, Italy, Poland, Slovakia, Tunisia, USA.

The Parliamentary Assembly of the Black Sea Economic Cooperation is the BSEC parliamentary dimension. The BSEC Business Council is composed of representatives from the business circles of the member states. The Black Sea Trade and Development Bank is considered as the financial pillar of the 